\title{
Good growth response to growth hormone treatment in the ring chromosome 15 syndrome
}

\author{
M Nuutinen, K Kouvalainen, M Knip
}

\begin{abstract}
Ring chromosome 15 syndrome is a rare condition in which severe growth retardation is a major finding. We report a 4 year old boy with the karyotype $46, X Y$, r(15)(p11.2q26.2) whom we have treated with recombinant human growth hormone (GH) for two years. During the first year of treatment, the insulin-like growth factor I increased from subnormal $4.2 \mathrm{nmol} / 1$ to normal $13.8 \mathrm{nmol} / 1$ and the insulin-like growth factor binding protein 3 levels increased from 2.6 to $3.8 \mathrm{mg} /$, whereas high binding protein 1 concentrations normalised from $52 \cdot 0$ to $16 \cdot 7 \mu \mathrm{g} / \mathrm{l}$. During the two years of treatment his relative height improved from -6.2 SD to -4.4 SD and the predicted adult height from $159.6 \mathrm{~cm}$ to $163.5 \mathrm{~cm}$. Owing to the good growth response, we have decided to continue GH treatment.
\end{abstract}

(f Med Genet 1995;32:486-487)

Ring chromosome 15 is a rare condition resulting from breakage and closure of chromosomal material leading to a ring formation and loss of genetic material. ${ }^{12}$ According to Butler et $a l^{2} 27$ cases had been published by 1988. Since then six new cases have been described. ${ }^{3-7}$ Severe growth retardation is a major and constant finding in this syndrome, ${ }^{2}$ but no reports on $\mathrm{GH}$ treatment have been published. We report here a 4 year old boy whom we have treated with recombinant human $\mathrm{GH}$ for two years in order to test whether he would benefit from GH therapy. A remarkable acceleration in growth velocity, as well as a substantial increase in relative height and predicted adult height was observed. During the first year of treatment, we repeatedly measured the circulating concentrations of IGF-I, IGFBP-1 and IGFBP-3. ${ }^{89}$

Case report

The proband's karyotype was 46,XY, $r(15)$ (p11.2q26.2). At birth the boy was small for gestational age ( 40 weeks, $2310 \mathrm{~g}, 43.0 \mathrm{~cm}$ ), and his relative height was $-4.0 \mathrm{SD}$. A chromosome analysis was therefore performed, and the diagnosis was made in the neonatal period. Failure to grow was the main symptom from birth, and at the age of 7 months his relative height was $-6.2 \mathrm{SD}$ and relative weight approximately $78 \%$. He also presented several other (9/13) features typical of the ring chromosome 15 syndrome (table 1 ).
Peak GH response to clonidine stimulation was good $(35.6 \mu \mathrm{g} / \mathrm{l})$ at the age of 2 years 3 months, but low $(5.3 \mu \mathrm{g} / \mathrm{l})$ in response to insulin induced hypoglycaemia (lowest blood glucose $1.5 \mathrm{mmol} / \mathrm{l}$ ). Other possible causes for growth retardation (coeliac disease, hypothyroidism) were excluded.

At the age of 2 years 3 months, his GP bone age was 1 year $(-3.2 \mathrm{SD})$, height $70 \cdot 2 \mathrm{~cm}$ $(-6.2 \mathrm{SD})$, weight $6.3 \mathrm{~kg}(77 \%)$, sitting height $41.7 \mathrm{~cm}(59.4 \%)$, and treatment with recombinant human GH (Saizen, Serono) at a daily dose of 1 unit sc was started. His relative height and predicted adult height improved continuously on GH therapy. During the two years of treatment his growth velocity increased from $5.9 \mathrm{~cm} /$ year to $8.5 \mathrm{~cm} /$ year, that is, by $44 \%$ and his relative height improved by 1.8 $\mathrm{SD}$, that is to $-4 \cdot 4 \mathrm{SD}$ (table 2 ). His predicted adult height assessed according to the RocheWainer-Thissen method (RWT) ${ }^{10}$ increased during the same time from $159.6 \mathrm{~cm}$ to $163.5 \mathrm{~cm}$ (table 2). His relative sitting height remained normal. During the two year treatment his GP bone age advanced by one year (table 2).

In response to $\mathrm{GH}$ treatment the IGF-I doubled in one month from a starting level of $4.2 \mathrm{nmol} / 1$ to $8.3 \mathrm{nmol} / 1$ (table 2 ). The increase continued, subsequently reaching a level of $13.8 \mathrm{nmol} / 1$ after treatment for one year. The IGFBP-3 concentration was within the normal range before treatment, but increased by $66 \%$ over the first month of therapy. Thereafter the levels remained higher than the initial one. The pretreatment IGFBP-1 level was raised but normalised during treatment.

\section{Discussion}

Our case had nine of the 13 main features (table 1) of the ring chromosome 15 syndrome. ${ }^{2}$ $\mathrm{He}$ was diagnosed very early, since a sample

Table 1 Main clinical features and their frequency in the ring chromosome 15 syndrome according to Butler et al ${ }^{2}$ and their manifestations in our case

\begin{tabular}{lll}
\hline Clinical feature & Frequency (\%) & Our case \\
\hline Growth retardation & 100 & + \\
Mental retardation (variable) & 95 & Slight? \\
Microcephaly & 88 & + \\
Hypertelorism & 46 & - \\
Triangular face & 42 & + \\
Delayed bone age & 75 & + \\
Brachydactyly & 44 & + \\
Speech delay & 39 & + \\
Frontal bossing & 36 & + \\
Anomalous ears & 30 & - \\
Café au lait spots & 30 & + \\
Cryptorchidism & 30 & - \\
Cardiac anomalies & 30 & - \\
\hline
\end{tabular}


Table 2 Growth parameters, IGF-I, IGFBP-1, and IGFBP-3 concentrations during GH treatment started at the age of 2 years. Age related reference values for IGF-1, IGFBP-1, and IGFBP-3 from our own laboratory (range, $n=10)$ are given in parentheses under each parameter

\begin{tabular}{|c|c|c|c|c|c|c|c|c|c|c|c|}
\hline \multirow{2}{*}{$\begin{array}{c}\text { Age } \\
(y)\end{array}$} & \multicolumn{2}{|c|}{ Height } & \multirow{2}{*}{$\begin{array}{l}\text { Growth } \\
\text { velocity } \\
(\mathrm{cm} / \mathrm{y})\end{array}$} & \multicolumn{2}{|c|}{ Weight } & \multicolumn{2}{|c|}{ GP bone age } & \multirow{2}{*}{$\begin{array}{l}\text { Predicted adult } \\
\text { height } \\
(\mathrm{cm})\end{array}$} & \multirow{2}{*}{$\begin{array}{l}I G F-1 \\
(4 \cdot 4-15 \cdot 0) \\
(\mathrm{nmol} / \mathrm{l})\end{array}$} & \multirow{2}{*}{$\begin{array}{l}I G F B P-1 \\
(3 \cdot 8-19 \cdot 0) \\
(\mu g / l)\end{array}$} & \multirow{2}{*}{$\begin{array}{l}I G F B P-3 \\
(1 \cdot 5-4 \cdot 3) \\
(m g / l)\end{array}$} \\
\hline & $\mathrm{cm}$ & $S D$ & & $g$ & $\%$ & $y$ & $S D$ & & & & \\
\hline $2 \cdot 24$ & $70 \cdot 2$ & $-6 \cdot 2$ & $5 \cdot 9$ & 6300 & 77 & $1 \cdot 0$ & $-3 \cdot 2$ & $159 \cdot 6$ & $4 \cdot 2$ & $52 \cdot 6$ & $2 \cdot 6$ \\
\hline $2 \cdot 32$ & $71 \cdot 2$ & $-6 \cdot 0$ & 12.5 & 6570 & 77 & - & - & - & $8 \cdot 3$ & $4 \cdot 1$ & $4 \cdot 3$ \\
\hline $2 \cdot 47$ & $72 \cdot 7$ & $-5 \cdot 8$ & $10 \cdot 9$ & 6695 & 76 & - & - & - & $10 \cdot 3$ & 5.5 & 3.5 \\
\hline $2 \cdot 70$ & $75 \cdot 2$ & $-5 \cdot 5$ & 10.9 & 6940 & 72 & $1 \cdot 25$ & $-3 \cdot 1$ & 161.9 & $10 \cdot 0$ & 12.0 & 3.6 \\
\hline $3 \cdot 24$ & $80 \cdot 0$ & $-5 \cdot 0$ & $9 \cdot 8$ & 7850 & 74 & 1.5 & $-3 \cdot 2$ & 162.6 & 13.8 & 16.7 & $3 \cdot 8$ \\
\hline $4 \cdot 19$ & $86 \cdot 8$ & $-4 \cdot 4$ & $8 \cdot 5$ & 9100 & 73 & $2 \cdot 0$ & $-3 \cdot 5$ & 163.5 & - & - & - \\
\hline
\end{tabular}

Predicted adult height was assessed according to Roche-Wainer-Thissen method. ${ }^{10}$

for chromosome analysis was taken at the age of a few days because of intrauterine growth retardation. The average age at diagnosis has been reported to be $8 \cdot 1$ years. $^{2}$

In our case, peak $\mathrm{GH}$ response to clonidine stimulation was normal but was low in response to insulin induced hypoglycaemia. Only in the case described by Kitatani et $a l^{5}$ have $\mathrm{GH}$ responses been reported. They observed a normal GH response to the combined arginineinsulin test on three occasions in their case.

It has been suggested that the decreased viability of fibroblasts obtained from these patients could be an in vitro reflection of growth failure. ${ }^{3}$ Recently, it was suggested that distal deletion of the long arm of chromosome 15 is associated with loss of an IGF-I receptor gene copy which may lead to an abnormal number or structure of the receptors resulting in severe intrauterine growth retardation and postnatal growth failure. ${ }^{6}$ Tamura et $a l^{11}$ reported similar results in a patient with features of RussellSilver syndrome and assigned the IGF-I receptor gene to $15 \mathrm{q} 26.3$. However, intensive molecular genetic analysis of $15 q \rightarrow$ qter markers has shown that the cause of growth retardation in ring 15 syndrome or Russell-Silver syndrome is not always the loss of genetic material on the distal long arm of chromosome $15 .{ }^{1213}$ Our results, showing a low IFG-I level before GH treatment, do not support a loss of the IGF-I receptor gene in the present case, since IGF-I receptor defects are associated with normal or increased IGF-I concentrations.

As far as we know, there have been no previous reports published on the results of $\mathrm{GH}$ therapy in the ring chromosome 15 syndrome. Our results suggest that $\mathrm{GH}$ therapy improves growth and predicted final height considerably in this syndrome, and we have therefore decided to continue treatment. This seems to be justified, since growth retardation is severe in most cases and may complicate everyday ac- tivities of these patients as adults. ${ }^{17}$ However, the decision on possible $\mathrm{GH}$ treatment should be made taking into account the complete spectrum of symptoms, for example, the degree of mental retardation, characteristic of this syndrome.

We would like to thank Sirpa Anttila for her skilful technical We would like to thank Sirpa Anttila for her skilful technical assistance and

1 Fryns JP, Kleckzkowska A, Buttiens $M$, Jonckheere $P$, Brouckmans-Buttiens $\mathrm{K}$, van den Berghe $\mathrm{H}$. Ring chroBrouckmans-Buttiens $K$, van den Berghe $H$. Ring chro-
mosome 15 syndrome. Further delineation of the adult mosome 15 syndrome. Further delineation

2 Butler MG, Fogo AB, Fuchs DA, Collins FS, Dev VG Butler MG, Fogo AB, Fuchs DA, Collins FS, Dev VG,
Phillips JA III. Brief clinical report and review. Two patients with ring chromosome 15 syndrome. $A m \mathcal{F ~ M e d}$ Genet 1988:29:149-54.

3 Kosztolányi G. Decreased cell viability of fibroblasts from two patients with ring chromosome: an in vitro reflection of growth failure? Am $\mathcal{F}$ Med Genet 1987;28:181-4.

4 De Jong G, Rossouw RA, Retief AE. Ring chromosome 15 in a patient with features of Fryns syndrome. $f$ Med Genet 1989;26:469-70.

5 Kitatani M, Takahashi H, Ozaki M, Okino E, Maruoka T. A case of ring chromosome 15 accompanied by almost normal intelligence. Hum Genet 1990;85:138-9.

6 Roback EW, Barakat AJ, Dev VG, Mbikay M, Chrétien M, Butler MG. An infant with deletion of the distal long arm of chromosome 15 (q26.1 $\rightarrow$ qter) and loss of insulin-likegrowth factor 1 receptor gene. Am $\mathcal{F}$ Med Genet 1991;38: 74-9.

7 Horigome Y, Kondo I, Kuwajima K, Suzuki T. Familial occurrence of chromosome 15. Clin Genet 1992;41:17880.

8 Pekonen F, Kärkkäinen T, Tanner P, Weber T, Rutanen EM. A monoclonal antibody-based immunoradiometric assay for low molecular weight insulin-like growth factor binding protein/placental protein 12. F Immunoassay 1989 10:325-37.

9 Blum WF, Ranke MB, Kietzmann K, Gauggel E, Zeise HJ, Bierich JR. A specific radioimmunoassay for growth hormone $(\mathrm{GH})$-dependent somatomedin-binding protein its use for diagnosis of $\mathrm{GH}$ deficiency. $\mathcal{F}$ Clin Endocrino Metab 1990;70:1504-12.

10 Roche AF, Weiner H, Thissen D. The RWT method for the prediction of adult stature. Pediatrics 1975;56:1026-33.

11 Tamura $\mathrm{T}$, Tohma $\mathrm{T}$, Ohta $\mathrm{T}$, et al. Ring chromosome 15 involving deletion of the insulin-like growth factor receptor gene in a patient with features of Silver-Russell syndrome. Clin Dysmorphol 1993;2:106-13.

12 Butler MG, Driscoll DJ, Papenhausen PR, Johnson VP, Rogan PK. Analysis of $15 \mathrm{q} 25 \rightarrow$ qter markers with ring 15 Rogan PK. Analysis of 15q25 $\rightarrow$ qter markers with ring 15
and Russell-Silver syndromes. Am $\mathcal{F}$ Hum Genet 1992;53: and Russe

13 Butler MG, Woodward AL, Driscoll DJ, et al. Molecular genetic analysis of $15 \mathrm{q} \rightarrow$ qter markers in patients with ring 15 and Russell-Silver syndromes. Cytogenet Cell Genet 1994;67:15. 